\title{
The projects of local governments' health policy programs in the area of therapeutic rehabilitation reviewed by the Agency for Health Technology Assessment and Tariff System [AOTMiT] in 2010-2017
}

\author{
Magdalena A. Mrożek-Gąsiorowska
}

Health Economics and Social Security Department, Institute of Public Health, Faculty of Health Sciences, Jagiellonian University Collegium Medicum

Address for correspondence: Health Economics and Social Security Department, Institute of Public Health, Faculty of Health Sciences, Jagiellonian University Collegium Medicum, Grzegórzecka 20, 31-531 Cracow, magdalena.mrozekgasiorowska@uj.edu.pl

\section{Abstract}

Since 2010, the Agency for Health Technology Assessment and Tariff System (AOTMiT) has issued its opinions on health policy programs (PPZ), including therapeutic rehabilitation. Of 1,813 opinions submitted on the programs, 6.9\% (126 opinions) have concerned therapeutic rehabilitation. The purpose of the study is to evaluate the proportion of and determining factors of the negative opinions presented by the AOTMiT. It has been demonstrated that nearly a quarter (23.5\% in 2017) of the projects in the field of therapeutic rehabilitation are negatively assessed by the Agency, the most common reason for the negative opinion (72.4\%) being inadequate project preparation. The new scheme of PPZ developed by the Agency should make it easier for local governments to design a program, thus significantly reducing the number of negative opinions on therapeutic rehabilitation programs.

\section{Key words: therapeutic rehabilitation, Iocal government, health policy program, The Agency for Health Technology Assessment and Tariff System, health technology assessment}

Słowa kluczowe: rehabilitacja lecznicza, samorząd terytorialny, program polityki zdrowotnej, Agencja Oceny Technologii Medycznych i Taryfikacji, ocena technologii medycznych

\section{Introduction}

Properly implemented and consistently conducted therapeutic rehabilitation complements the treatment process, yielding full and long-lasting therapeutic effects that prevent disability. It reduces the global burden of disease and improves the quality of life for patients. The importance of rehabilitation in the treatment process that leads to long-term health effects is reflected in the concept of the Polish model of rehabilitation, based on four principles: universality, comprehensiveness, earliness and continuity [1]. The implementation of this model has encountered numerous barriers, related not only to financial constraints.

The services of therapeutic rehabilitation in Poland are financed by the National Health Fund (NFZ), the Social Insurance Institution (ZUS), the Agricultural Social Insurance Fund (KRUS), the State Fund for Rehabilitation of Disabled (PFRON) and local governments [2]. However, access to therapeutic rehabilitation services is limited and diminishes year by year [3], which has prompted the postulate of preparing a national program 
for the prevention and treatment of chronic diseases and the rehabilitation of people with functional limitations, as well as designing a comprehensive rehabilitation system (therapeutic, social and professional) [4].

We shall consider and analyse those health policy programs that include therapeutic rehabilitation services financed by local government units. ${ }^{1}$ By introducing a program involving medical rehabilitation services, the local government aims at improving accessibility and reducing the waiting times for these benefits in the community. The local government not only develops and implements health policy programs resulting from the identified health needs and the health status of residents, but also evaluates their effects.

The aim of the paper is to see whether and to what extent local governments prepare and apply health policy programs (PPZ) that would take into account the implementation of services in the field of therapeutic rehabilitation, including those implemented in health resorts. Particular attention was paid to the already developed PPZs directed at rehabilitation which received a negative opinion of the AOTMiT - in order to determine its cause. Also considered was the possible impact that recent legislative changes in health policy programs had on the increase in the acceptance and the implementation scale of those PPZs that include therapeutic rehabilitation.

The health policy program (PPZ) is a set of planned and intended health care activities recognized as effective, safe and justified, and enabling the fulfilment of objectives, i.e. identifying and meeting, within a given time, the specific health needs and improving the health of a given group of beneficiaries - developed, implemented, realized and financed by the minister or a local government unit (Article 5, point 29a of the Act of 27 August 2004 on publicly-funded health care services [Journal of Laws 2004 No. 210 item 2135, as amended]). The PPZs may specifically refer to important epidemiological phenomena and other significant health problems affecting the entire or limited group of beneficiaries - with the existing possibilities of eliminating or reducing these problems - as well as to the implementation of new medical procedures and preventive measures. Chapter 4 of the Act on publicly-funded health care services specifies the rules concerning the process of developing, implementing, realizing and financing the PPZ.

\section{Leval basis and scope of analysis}

All PPZ projects developed by the local authorities, with the exception of PPZs that are a continuation of the program implemented in the previous period, should be submitted for an opinion to the Agency for Health Technology Assessment and Tariff System (AOTMiT), and the Agency is required to prepare an opinion on this PPZ within 2 months from the date of receiving the program (Article 48a of the Act [5]), taking into account its impact on improving the health of citizens, bearing in mind the health priorities and incidence, morbidity or mortality rates based on the current medical knowledge (Table I) (Art. 31a paragraph 1 of the Act [5]). To facilitate the development of PPZ projects to local governments, the AOTMiT has prepared practical guidelines for the planning, implementation and realization of health policy programs [6] and the PPZ scheme [7], which are available on the Agency's website.

It should be noted that when issuing opinions on local government programs, the AOTMiT draws on the current reliable clinical guidelines developed by foreign and national experts regarding the intervention proposed in the project in a given target population, as well as on scientific evidence, results of clinical trials evaluating the effectiveness and safety of assessed interventions, also taking into account the costs of planned interventions, the available reimbursement recommendations and cost-effectiveness of services. The AOTMiT prepares reports evaluating the PPZs in accordance with the principles of Evidence Based Medicine (EBM) and Health Technology Assessment (HTA). The process of issuing opinions by the AOTMiT regarding PPZ projects meets the global standards in this field and is based on the same assessment of health services that is used by institutions responsible for health technology assessment around the world and on which recommendations and guidelines issued by such institutions as the National Institute of Health and Care Excellence (NICE) are founded.

In 2016, the Supreme Audit Office (NIK) carried out an audit of the implementation of the PPZs by local government units. The audit report indicated that the difficult financial situation of many local governments (income shortages and significant budget deficits) means that few local governments decide to implement the PPZ, and therefore the projects constitute a small share in the funding of health services and do not contribute significantly to improving the health and quality of life of Polish citizens. In 2015, the share of local government expenditures on the implementation of PPZs in the total expenditure of all local government units amounted to $0.042 \%$. The most important systemic flaws indicated by the NIK included the differences in access to PPZs, which depends on the material status of the local government, and lack of precise guidelines on how the program should be developed, implemented, realized and monitored, as well as the insufficient coordination of program implementation, resulting in running the same activities in a given area. In the majority of local government units controlled by the Supreme Audit Office, irregularities in acquiring AOTMiT opinions were found, consisting both in the implementation of programs without submitting them for an opinion, and in the launching of selection procedures and implementation of programs before the opinion was obtained. The problem for local governments was the long waiting time of issuing opinions, usually exceeding the regulatory framework [8].

The results of the NIK audit and the recommendations contained in the report were followed by the Act of 29 September 2017 amending the Act on publicly-funded 


\begin{tabular}{|l|}
\hline \multicolumn{1}{|c|}{ Criterion } \\
\hline Impact on improving the health of citizens, including: \\
\hline a) health priorities \\
\hline $\begin{array}{l}\text { b) incidence, morbidity or mortality rates based on the current } \\
\text { medical knowledge }\end{array}$ \\
\hline Effects of the disease or health condition, in particular leading to: \\
\hline a) premature death \\
\hline b) inability to live independently \\
\hline c) incapacity to work \\
\hline d) chronic suffering or chronic illness \\
\hline e) lowering the quality of life \\
\hline $\begin{array}{l}\text { The importance for the health of citizens, taking into account the } \\
\text { need to: }\end{array}$ \\
\hline a) save lives and achieve a full recovery \\
\hline b) save lives and improve health \\
\hline c) prevent premature death \\
\hline $\begin{array}{l}\text { d) improve the quality of life without a significant impact on its } \\
\text { length }\end{array}$ \\
\hline Clinical efficacy and safety \\
\hline The ratio of obtained health benefits to health risk \\
\hline The ratio of costs to obtained health effects \\
\hline $\begin{array}{l}\text { Financial consequences for the health care system, including for } \\
\text { the health care entity obliged to finance health care services from } \\
\text { public funds }\end{array}$ \\
\hline
\end{tabular}

Table I. Criteria considered by AOTMiT when reviewing $P P Z$ projects [5].

Source: Own study.

health care services and certain other acts. Accordingly, changes have been introduced in the rules of preparing and evaluating the PPZs, the process of creating the PPZ itself being simplified and clarified. The Act has also changed the provisions of the Act of 17 December 2004 on the liability for the breach of public finance discipline (Journal of Laws of 2017, item 1311, as amended) [9], indicating that incurring liabilities in connection with the implementation of a health policy program whose project was not submitted for the opinion of the AOTMiT, despite the existence of such an obligation, and whose draft was negatively evaluated by the AOTMiT, indeed constitutes a breach of the public finance discipline. Those health policy programs whose implementation and financing were initiated before the aforementioned changes became binding, and for which the AOTMiT issued a negative opinion based on the existing regulations, may be implemented and financed according to the existing principles, but no longer than until December 31, 2019 [10]. Therefore, since the above changes came into force, only a positive (or conditionally positive) opinion of the AOTMiT enables the implementation of local health policy programs.

On 24 October 2017, the AOTMiT published a modified PPZ model on its website. According to the AOT-
MiT's message, the new PPZ model is a simplified version, including - among other modifications - fewer detailed points. The template is clearer, easier to read and easier to fill in, in order to facilitate it to the local government units the process of preparing a correct PPZ project [11].

It is from 2010 onwards that the President of the AOTMiT has issued opinions on PPZ projects, including PPZ projects targeted at therapeutic rehabilitation, and so the analysis included the opinions issued in the years 2010-2017 and published on the AOTMiT website (http://www.aotm.gov.pl/www/). In total, up to now (i.e. by 6 October, 2017) 1,813 PPZ projects have been issued an opinion. The search for the AOTMiT's opinion on PPZ concerning therapeutic rehabilitation was carried out on the basis of titles or complete texts of these opinions in those cases where the title of the document did not explicitly state the scope of the PPZ project proposed by the local government [12].

\section{Results of analysis of health policy proyrams reviewed by AOTMiT}

Based on a review of all the opinions issued by the AOTMiT regarding PPZ projects, it can be concluded that the most projects so far reviewed by AOTMiT concerned protective vaccination programs (mainly vaccinations against HPV, influenza, pneumococcal and meningococcal infections - in 2017 this constituted nearly $35 \%$ of the evaluated PPZ projects). Other interventions were less frequently selected by local government units. Second most frequent intervention was therapeutic rehabilitation for children and/or adults with disability or at its risk, as part of various clinical indications (diseases) and using different types of rehabilitation procedures. In addition to preventive vaccinations and medical rehabilitation, local governments also develop PPZs targeted at preventive programs for the early detection of cancer (most commonly breast cancer, prostate cancer and colorectal cancer), prevention and treatment of caries, posture defects, and hearing, sight and/or speech defects in children, prevention or treatment of overweight and obesity (including programs promoting healthy eating habits and prevention or treatment of diabetes), interventions in the field of mental health, addiction prevention and treatment as well as preventive and educational activities for pregnant women and mothers, and infertility treatment programs (Table II).

Every year, 200 to 300 opinions are issued on PPZ projects elaborated by local government units or the minister. In total, during the period under consideration (2010 - 6 October 2017), the AOTMiT issued 126 opinions on PPZ projects concerning therapeutic rehabilitation (including one project concerning health resort rehabilitation), which accounted for $6.9 \%$ of all submitted PPZ projects. Of 267 opinions presented in 2017 by the AOTMiT on PPZ projects (until 6 October, 2017), 6.4\% (17 opinions) concerned PPZs targeted at the implementation of interventions in the field of therapeutic rehabilitation (Figure 1).

Although PPZs can be developed at any level of local governments ${ }^{2}$, the majority are implemented by the 


\begin{tabular}{|c|c|c|c|c|c|}
\hline \multirow[t]{2}{*}{ Areas of health policy programs } & \multirow{2}{*}{$\begin{array}{c}\text { Number of } \\
\text { opinions }\end{array}$} & \multicolumn{2}{|c|}{ Positive opinion } & \multicolumn{2}{|c|}{ Negative opinion } \\
\hline & & $\mathrm{n}$ & $\%$ & $\mathrm{n}$ & $\%$ \\
\hline TOTAL & 267 & 196 & 73.4 & 71 & 26.6 \\
\hline preventive vaccinations & 93 & 87 & 93.5 & 6 & 6.5 \\
\hline therapeutic rehabilitation & 17 & 13 & 76.5 & 4 & 23.5 \\
\hline tooth decay in children & 16 & 16 & 100.0 & 0 & 0.0 \\
\hline overweight and obesity & 15 & 15 & 100.0 & 0 & 0.0 \\
\hline defects in posture in children & 14 & 4 & 28.6 & 10 & 71.4 \\
\hline other specific non-cancerous diseases & 11 & 4 & 36.4 & 7 & 63.6 \\
\hline prostate cancer & 10 & 2 & 20.0 & 8 & 80.0 \\
\hline hearing, sight and/or speech defects in children & 10 & 5 & 50.0 & 5 & 50.0 \\
\hline in vitro infertility treatment & 8 & 8 & 100.0 & 0 & 0.0 \\
\hline diabetes & 8 & 6 & 75.0 & 2 & 25.0 \\
\hline other/various cancers & 8 & 2 & 25.0 & 6 & 75.0 \\
\hline mother and child care & 7 & 7 & 100.0 & 0 & 0.0 \\
\hline prophylaxis - complex projects & 7 & 2 & 28.6 & 5 & 71.4 \\
\hline Lyme disease (other than vaccination) & 6 & 6 & 100.0 & 0 & 0.0 \\
\hline breast cancer & 6 & 1 & 16.7 & 5 & 83.3 \\
\hline circulatory system & 5 & 4 & 80.0 & 1 & 20.0 \\
\hline viral hepatitis & 5 & 3 & 60.0 & 2 & 40.0 \\
\hline developmental disorders and/or autism & 3 & 3 & 100.0 & 0 & 0.0 \\
\hline vision dysfunction/glaucoma in adults & 3 & 1 & 33.3 & 2 & 66.7 \\
\hline occupational exposure and occupational diseases & 3 & 2 & 66.7 & 1 & 33.3 \\
\hline poisoning with heavy metals or benzene (environmental) & 3 & 0 & 0.0 & 3 & 100.0 \\
\hline tuberculosis & 2 & 2 & 100.0 & 0 & 0.0 \\
\hline pre-medical aid/emergency medical services & 2 & 2 & 100.0 & 0 & 0.0 \\
\hline school medicine & 2 & 0 & 0.0 & 2 & 100.0 \\
\hline prevention in the elderly group & 2 & 1 & 50.0 & 1 & 50.0 \\
\hline infertility treatment - excluding in vitro & 1 & 0 & 0.0 & 1 & 100.0 \\
\hline
\end{tabular}

Table II. Areas of PPZs reviewed by AOTMiT in 2017 (until 6 November, 2017).

Source: Own study based on the PPZ projects reviewed by AOTMiT.

gmina (municipal government). Looking at the total of all projects reviewed by the AOTMiT, this applies to approximately three-quarters of them (203 PPZs, i.e. 76\% in 2017). The remaining projects are implemented by the provincial government - voivodeships (44 PPZs, i.e. $16.5 \%$ in 2017), powiats $(5.2 \%, 14 \mathrm{PPZ}$ in 2017) or the Minister of Health $(2.2 \%, 6$ PPZs in 2017). In the case of the projects targeted at therapeutic rehabilitation, the share of gmina projects is even larger, and amounts to $88.1 \%$. The remaining projects are primarily realized by the voivodeships $(10.3 \%)$, whereas the powiats developed only one project in 2010-2017 (the powiat of Mikołów). In addition, one PPZ was developed by the Commune Union of Copper Basin (Zwiazek Gmin Zagłębia Miedziowego). There is no nationwide health policy program focused on the implementation of services in the field of therapeutic rehabilitation (Table III).
The percentage of PPZ projects that have been negatively evaluated by the AOTMiT has remained relatively stable over the past years. In total, in 2017 , every fourth (26.6\%) project submitted to the AOTMiT for an opinion was negatively assessed by the Agency (Table IV). In the case of projects related to therapeutic rehabilitation, this share was slightly lower and in 2017 amounted to $23.5 \%$ (Table V).

There are some differences in the number of total projects submitted to the AOTMiT for an opinion (Table VI) and those involving therapeutic rehabilitation, as well as in the number of positive and negative opinions between voivodships. The largest number of rehabilitation projects (33) were submitted by local government units in the Śląskie Voivodeship, while the least were presented by the governments of the Lubelskie Voivodeship (2), Warmińsko-Mazurskie (1) and Wielkopolskie (1), while in 


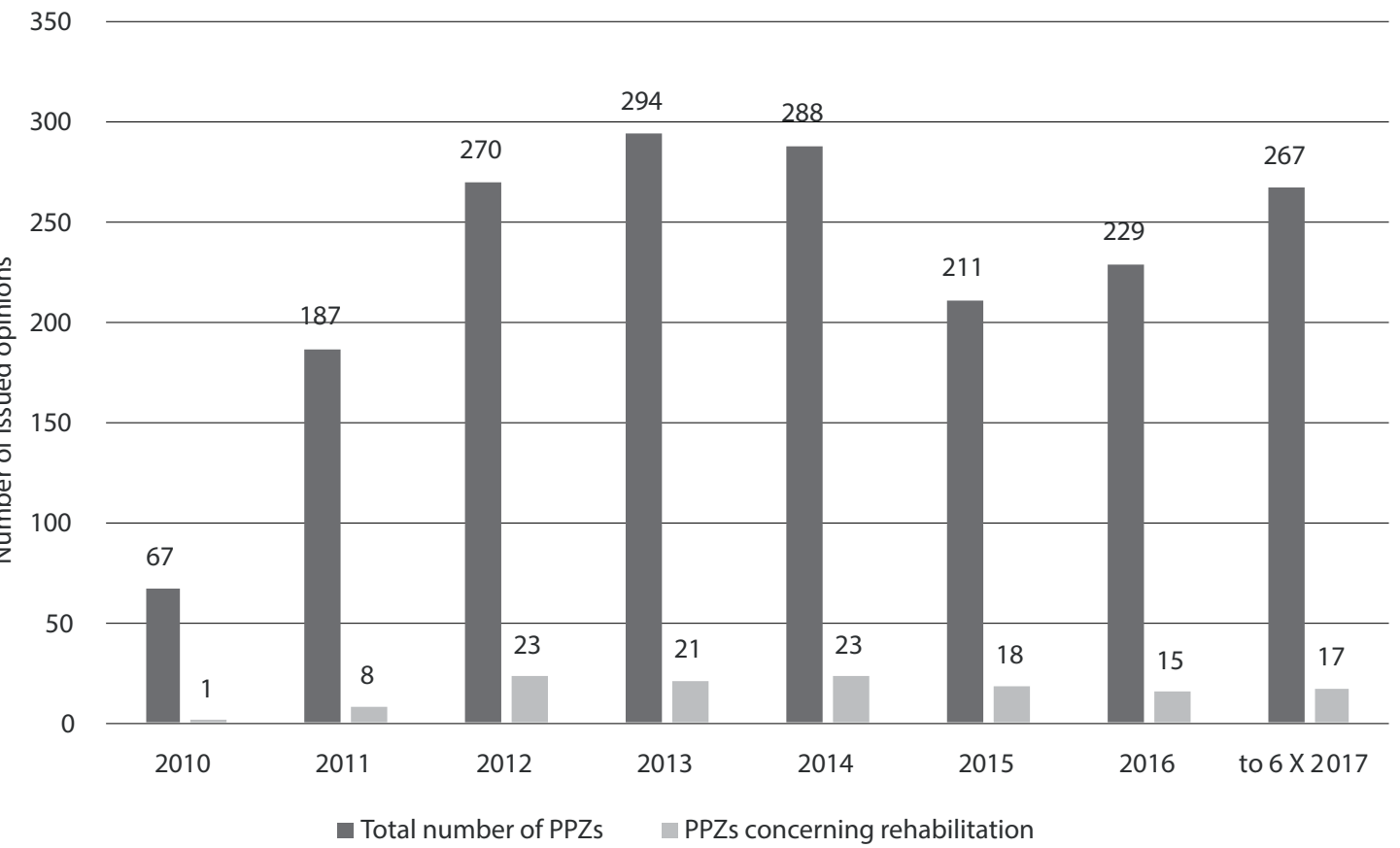

Figure 1. Number of opinions issued by AOTMiT on the total number of PPZs and PPZs concerning rehabilitation, in the years 2010-2017.

Source: Own study based on the PPZ projects reviewed by AOTMiT.

\begin{tabular}{|c|c|c|c|c|c|}
\hline Year & TOTAL & $\begin{array}{c}\text { Gmina } \\
\text { government }\end{array}$ & Powiat/Region government & $\begin{array}{l}\text { Voivodeship } \\
\text { government }\end{array}$ & Ministry \\
\hline 2010 & 1 & 0 & 0 & $\begin{array}{l}1 \\
\text { (Kujawsko-Pomorskie Voivo- } \\
\text { deship) }\end{array}$ & 0 \\
\hline 2011 & 8 & 8 & 0 & 0 & 0 \\
\hline 2012 & 23 & 22 & $\begin{array}{l}1 \\
\text { (Commune Union of Copper Basin) }\end{array}$ & 0 & 0 \\
\hline 2013 & 21 & 20 & 0 & $\begin{array}{l}1 \\
\text { (Kujawsko-Pomorskie Voivo- } \\
\text { deship) }\end{array}$ & 0 \\
\hline 2014 & 23 & 21 & 0 & $\begin{array}{l}2 \\
\text { (Opolskie and Mazowieckie } \\
\text { Voivodeships) }\end{array}$ & 0 \\
\hline 2015 & 18 & 16 & $\begin{array}{l}1 \\
\text { (powiat of Mikołów) }\end{array}$ & $\begin{array}{l}1 \\
\text { (Lódzkie Voivodeship) }\end{array}$ & 0 \\
\hline 2016 & 15 & 13 & 0 & $\begin{array}{l}2 \\
\text { (Łódzkie and Opolskie Voivo- } \\
\text { deships) }\end{array}$ & 0 \\
\hline $\begin{array}{l}2017 \text { (until } \\
6 \text { October) }\end{array}$ & 17 & 11 & 0 & $\begin{array}{l}6 \\
\text { (Warmińsko-Mazurskie, Podlaskie, } \\
\text { Łódzkie, Małopolskie, Świętokrzy- } \\
\text { skie [x2] Voivodeships) }\end{array}$ & 0 \\
\hline $\begin{array}{l}2010-6 \text { October } \\
2017\end{array}$ & 126 & 111 & 2 & 13 & 0 \\
\hline
\end{tabular}

Table III. Health care entities developing PPZ projects concerning rehabilitation, reviewed by AOTMiT in the years 2010-2017. Source: Own study based on the PPZ projects reviewed by AOTMiT. 


\begin{tabular}{|c|c|c|c|c|c|c|c|c|c|c|}
\hline \multirow{3}{*}{ Year } & \multicolumn{10}{|c|}{ The number $(\%)$ of positive $(+)$ and negative $(-)$ opinions } \\
\hline & \multicolumn{2}{|c|}{ Gmina government } & \multicolumn{2}{|c|}{ Powiat government } & \multicolumn{2}{|c|}{$\begin{array}{c}\text { Voivodeship / Region } \\
\text { government }\end{array}$} & \multicolumn{2}{|c|}{ Ministry } & \multicolumn{2}{|c|}{ TOTAL } \\
\hline & + & - & + & - & + & - & + & - & + & - \\
\hline 2015 & $\begin{array}{c}129 \\
(72.9)\end{array}$ & $\begin{array}{c}48 \\
(27.1)\end{array}$ & $\begin{array}{c}13 \\
(68.4)\end{array}$ & $\begin{array}{c}6 \\
(31.6)\end{array}$ & $\begin{array}{c}5 \\
(62.5)\end{array}$ & $\begin{array}{c}3 \\
(37.5)\end{array}$ & $\begin{array}{c}7 \\
(100.0)\end{array}$ & $\begin{array}{c}0 \\
(0.0)\end{array}$ & $\begin{array}{c}154 \\
(73.0)\end{array}$ & $\begin{array}{c}57 \\
(27.0)\end{array}$ \\
\hline 2016 & $\begin{array}{c}122 \\
(70.5)\end{array}$ & $\begin{array}{c}51 \\
(29.5)\end{array}$ & $\begin{array}{c}9 \\
(28.1)\end{array}$ & $\begin{array}{c}23 \\
(71.9)\end{array}$ & $\begin{array}{c}15 \\
(75.0) \\
\end{array}$ & $\begin{array}{c}5 \\
(25.0)\end{array}$ & $\begin{array}{c}4 \\
(100.0)\end{array}$ & $\begin{array}{c}0 \\
(0.0)\end{array}$ & $\begin{array}{c}150 \\
(65.5)\end{array}$ & $\begin{array}{c}79 \\
(34.5)\end{array}$ \\
\hline $\begin{array}{l}2017 \\
\text { (until } 6 \\
\text { October) }\end{array}$ & $\begin{array}{c}151 \\
(74.4)\end{array}$ & $\begin{array}{c}52 \\
(25.6)\end{array}$ & $\begin{array}{c}8 \\
(57.1)\end{array}$ & $\begin{array}{c}6 \\
(42.9)\end{array}$ & $\begin{array}{c}33 \\
(75.0)\end{array}$ & $\begin{array}{c}11 \\
(25.0)\end{array}$ & $\begin{array}{c}4 \\
(66.7)\end{array}$ & $\begin{array}{c}2 \\
(33.3)\end{array}$ & $\begin{array}{c}196 \\
(73.4)\end{array}$ & $\begin{array}{c}71 \\
(26.6)\end{array}$ \\
\hline
\end{tabular}

Table IV. The total number of opinions on PPZ projects issued by AOTMiT in 2015-2017.

Source: Own study based on the PPZ projects reviewed by AOTMiT.

\begin{tabular}{|l|c|c|c|c|}
\hline \multicolumn{1}{|c|}{ Year } & Positive opinions & Negative opinions & Total & Share of negative opinions [\%] \\
\hline 2010 & 0 & 1 & 1 & 100.0 \\
\hline 2011 & 7 & 1 & 8 & 12.5 \\
\hline 2012 & 16 & 7 & 23 & 30.4 \\
\hline 2013 & 18 & 3 & 21 & 14.3 \\
\hline 2014 & 17 & 6 & 18 & 26.1 \\
\hline 2015 & 16 & 2 & 15 & 33.3 \\
\hline 2016 & 10 & 5 & 17 & 23.5 \\
\hline $\begin{array}{l}2017 \\
\text { until 6 October) }\end{array}$ & 13 & 4 & 126 & 23.0 \\
\hline $2010-6$ October 2017 & 97 & 29 & & \\
\hline
\end{tabular}

Table V. Positive and negative opinions on PPZs concerning rehabilitation, issued by AOTMiT in 2010-2017.

Source: Own study based on the PPZ projects reviewed by AOTMiT.

\begin{tabular}{|c|c|c|c|c|c|c|c|}
\hline \multirow{2}{*}{ Voivodeship } & \multirow{2}{*}{$\begin{array}{c}\text { Number } \\
\text { of opinions }\end{array}$} & \multicolumn{2}{|c|}{ Gmina government } & \multicolumn{2}{|c|}{ Powiat government } & \multicolumn{2}{|c|}{$\begin{array}{c}\text { Voivodeship / } \\
\text { Region government }\end{array}$} \\
\hline & & + & - & + & - & + & - \\
\hline TOTAL & 261 & 151 & 52 & 8 & 6 & 33 & 11 \\
\hline Dolnośląskie & 22 & 12 & 9 & 0 & 0 & 0 & 1 \\
\hline Kujawsko-Pomorskie & 10 & 7 & 2 & 0 & 0 & 1 & 0 \\
\hline Lubelskie & 7 & 4 & 0 & 0 & 0 & 2 & 1 \\
\hline Lubuskie & 10 & 7 & 1 & 0 & 1 & 1 & 0 \\
\hline Łódzkie & 18 & 12 & 3 & 0 & 1 & 2 & 0 \\
\hline Małopolskie & 9 & 1 & 2 & 0 & 0 & 3 & 3 \\
\hline Mazowieckie & 29 & 18 & 6 & 2 & 0 & 3 & 0 \\
\hline Opolskie & 4 & 3 & 1 & 0 & 0 & 0 & 0 \\
\hline Podkarpackie & 12 & 4 & 6 & 0 & 0 & 2 & 0 \\
\hline Podlaskie & 8 & 2 & 1 & 0 & 0 & 5 & 0 \\
\hline Pomorskie & 25 & 18 & 4 & 3 & 0 & 0 & 0 \\
\hline Śląskie & 42 & 27 & 7 & 2 & 3 & 3 & 0 \\
\hline Świętokrzyskie & 24 & 17 & 0 & 1 & 0 & 5 & 1 \\
\hline Warmińsko-Mazurskie & 17 & 7 & 5 & 0 & 1 & 4 & 0 \\
\hline Wielkopolskie & 16 & 5 & 4 & 0 & 0 & 2 & 5 \\
\hline Zachodniopomorskie & 8 & 7 & 1 & 0 & 0 & 0 & 0 \\
\hline
\end{tabular}

Table VI. The total of PPZs reviewed by AOTMiT in 2017 (until 6 October 2017) by individual voivodeships.

Source: Own study based on the PPZ projects reviewed by AOTMiT. 
the case of the Podkarpackie Voivodeship, in 2010-2017, no PPZ projects concerning therapeutic rehabilitation were submitted to or reviewed by the AOTMiT (Table VII).

The rehabilitation services proposed under the PPZ projects often coincide with the services financed by public funds of the NFZ and/or ZUS/KRUS, or PFRON, especially if they are directed at disabled children and adolescents. Taking into account the comprehensive and complex nature of the rehabilitation process, these programs often include interventions in the field of rehabilitation as well as social and vocational rehabilitation. The PPZs most often include rehabilitation with the use of various methods of physical therapy and kinesiotherapy, as well as therapeutic massage - consistent with the referral and tailored to the individual needs of the patient; also rehabilitation of disabled children or adults in the case of dysfunctions of the musculoskeletal system or circulatory diseases (also following a stroke or acute coronary syndrome), as well as the rehabilitation of children and adolescents in the event of central nervous system disorders, cerebral palsy or autism. These programs are aimed mainly at supplementing therapeutic rehabilitation services available as part of guaranteed services.

The Agency has also issued opinions on those PPZ projects where the planned interventions were psychophysical rehabilitation in women after mastectomy, including prophylaxis and anti-edema therapy, such as lymphatic drainage procedures, tapping and group exer- cises conducted in a rehabilitation facility or in a pool. These benefits also coincide with both the therapeutic rehabilitation services funded by the NFZ and the benefits provided under the ZUS disability pension program.

Reviewing PPZ projects, the AOTMiT indicates that local government programs covering comprehensive therapy and rehabilitation of people with disabilities or dysfunctions seem justified due to the limited availability of services funded, for example, by the NFZ or ZUS. The purpose of many PPZs covering medical rehabilitation services is to quickly start the rehabilitation process and to provide recipients with the possibility of its continuation after using the guaranteed health services, and so especially at the beginning of the 2010-2017 period - the opinions indicate that the planned PPZs may support the health care system and disability pension prevention system, taking into account the long waiting times and the imposed low limits, especially in the case of therapeutic rehabilitation services funded by the NFZ. The most recent opinions on PPZ, published in 2017, indicate that in accordance with Art. 9a and 9b of the Act on publiclyfunded health care services, in order to meet the needs of the local community concerning health protection, the local government unit - taking into account the regional map of health needs, the priorities for the regional health policy and the access to health care services in the voivodeship - can finance the benefits guaranteed for the residents of this community under the contract with the

\begin{tabular}{|c|c|c|c|c|c|c|c|}
\hline \multirow[t]{2}{*}{ Voivodeship } & \multirow{2}{*}{$\begin{array}{l}\text { Number } \\
\text { of opinions }\end{array}$} & \multicolumn{2}{|c|}{ Gmina government } & \multicolumn{2}{|c|}{ Powiat government } & \multicolumn{2}{|c|}{$\begin{array}{c}\text { Voivodeship / } \\
\text { Region government }\end{array}$} \\
\hline & & + & - & + & - & + & - \\
\hline RAZEM & 118 & 77 & 26 & 2 & 0 & 11 & 2 \\
\hline Dolnośląskie & 19 & 13 & 5 & 1 & 0 & 0 & 0 \\
\hline Kujawsko-Pomorskie & 6 & 4 & 0 & 0 & 0 & 1 & 1 \\
\hline Lubelskie & 2 & 2 & 0 & 0 & 0 & 0 & 0 \\
\hline Lubuskie & 4 & 4 & 0 & 0 & 0 & 0 & 0 \\
\hline Łódzkie & 6 & 3 & 0 & 0 & 0 & 3 & 0 \\
\hline Małopolskie & 8 & 5 & 2 & 0 & 0 & 1 & 0 \\
\hline Mazowieckie & 10 & 6 & 3 & 0 & 0 & 1 & 0 \\
\hline Opolskie & 8 & 3 & 3 & 0 & 0 & 1 & 1 \\
\hline Podkarpackie & 0 & 0 & 0 & 0 & 0 & 0 & 0 \\
\hline Podlaskie & 6 & 2 & 3 & 0 & 0 & 1 & 0 \\
\hline Pomorskie & 5 & 4 & 1 & 0 & 0 & 0 & 0 \\
\hline Śląskie & 33 & 23 & 9 & 1 & 0 & 0 & 0 \\
\hline Świętokrzyskie & 5 & 3 & 0 & 0 & 0 & 2 & 0 \\
\hline Warmińsko-Mazurskie & 1 & 0 & 0 & 0 & 0 & 1 & 0 \\
\hline Wielkopolskie & 1 & 1 & 0 & 0 & 0 & 0 & 0 \\
\hline Zachodniopomorskie & 4 & 4 & 0 & 0 & 0 & 0 & 0 \\
\hline
\end{tabular}

* The analysis does not include 8 opinions on gmina PPZs issued by AOTMiT in 2011, because the data concerning the entity developing the PPZ project were blacked out in these opinions; the analysis takes into account the opinions issued until 6 October 2017.

Table VII. Opinions about PPZ regarding medical rehabilitation issued by AOTMiT in 2010-2017, broken down by region and entity developing the PPZ project*.

Source: Own study based on the PPZ projects reviewed by AOTMiT. 
service provider. Considering the above, there is no need to prepare a health policy program in this area.

In the opinions issued for the PPZ projects aimed at therapeutic rehabilitation, it was also pointed out that the health programs devoted to actions preventing the occurrence and aggravation of disability do not include a welldefined health problem and a strictly defined population. Disability is a term defining a long-term condition in which there are certain limitations in the proper functioning of a person. This concept refers to a population differentiated in terms of the type (category) of disability, the period of life in which it occurred, the cause or degree of disability, and therefore a population with different therapeutic, as well as educational or social requirements, for which it is possible to apply various interventions.

It was also indicated that the clinical guidelines or recommendations for the therapeutic treatment emphasize the need to ensure that the benefits are comprehensive and multidisciplinary, that the rehabilitation process is complex, prompt, contains intensive therapeutic activities and continuity, and it was also noted that the rehabilitation plan should be adapted to the needs arising from the patient's condition and the scope of the physiotherapeutic help needed. These elements determine the effectiveness of the rehabilitation therapy. The patients' rehabilitation needs differ significantly even within one disease entity, and therefore rehabilitation therapy should be individualized and conducted based on an individual intervention plan, defining the goals, type(s), frequency and intensity of activities appropriate to the specific needs and capacities of the patients. The recommendations included in the clinical guidelines accord that rehabilitation cannot be considered a separate form or stage of therapy, but must be integrated with the secondary prevention benefits, as it is one of its aspects. In addition, therapeutic rehabilitation gives the opportunity to learn and encourage positive health behaviours and increase compliance with the recommended pharmacotherapy.

With regard to health resort rehabilitation, only one PPZ was found, reviewed by the AOTMiT in 2012 (Opinion No. 51/2012 dated 23 April 2012). This program concerned the treatment of obesity and was to be implemented by the city of Kraków. The main goal of the program was to develop and implement a model of health resort treatment of obesity in groups of the highest risk of developing type 2 diabetes, hypertension and atherosclerosis. The project assumed supervising groups of 20 people in ten 21-day stays a year in a health resort in the Małopolskie Voivodeship, selected following a public tender. During the stay, interventions in the field of physical rehabilitation were planned (field activities - marches, jog-trots, Nordic walking, general gymnastics, hydrotherapy, physiotherapy, water aerobics in a pool, water aerobics using equipment, hydromassages in a pool). Interventions also included a lowcalorie reducing diet as well as education and lifestyle modification.

The AOTMiT issued a negative opinion on this project, justifying that no reliable scientific evidence was found that health resort treatment contributes to a radical change in the diet and lifestyle of obese people, and the expectation that during a 21-day period patients will change completely and forever their eating and lifestyles is completely unfounded. In addition, the program was indicated not to be cost-effective. The explanatory memorandum of the opinion also indicated that the funds envisaged for the implementation of the program could be better used for changing the environment and shaping pro-health attitudes in a manner that would facilitate physical activity and discourage uncontrolled and irrational nutrition. It was also added that research [13] shows that obesity is largely the result of the nutrition and lifestyle dominant in a given community, and like an epidemic, it spreads mainly through social environments. Therefore, it is impossible to change the individual's lifestyle without a radical change in the life of the entire community.

\section{Reasons for the neyative opinions issued by the AOTMiT on the projects of health policy programs}

Projects aimed at therapeutic rehabilitation constitute a significant group of PPZ projects reviewed by the AOTMiT (although they amount to only about 7\% of these projects, the therapeutic rehabilitation is - after preventive vaccination - the second most frequent area of interest of local governments in relation to the PPZ). Most of these types of PPZ projects are assessed positively. Of all the opinions on PPZ projects concerning rehabilitation, 29 are negative -2 projects prepared by voivodeship governments and 27 by gmina governments.

The most common reason for issuing a negative opinion on the project was lack of basic / key project elements and/ or a large number of inaccuracies and ambiguities, which - according to the AOTMiT - hindered the overall verification of the project and evaluation of planned interventions, often described too vaguely. This concerned 21 (72.4\%) of 29 negative opinions, including 20 projects prepared by the gmina government and 1 voivodeship government project. These opinions indicated that the projects concern significant health problems and did not question the applicability of selected services in the field of therapeutic rehabilitation, which mostly complemented the guaranteed services funded by public funds of the National Health Fund (the purpose of the PPZ was to increase the availability of rehabilitation procedures and reduce the waiting time of their implementation by providing recipients of the program with the possibility of continuing the rehabilitation process after using the guaranteed health services).

An example of a PPZ project that received a negative opinion from the AOTMiT due to the above-mentioned factors is the draft program developed by the Kujawsko-Pomorskie Voivodeship in 2010, titled "Regional program to combat obesity and its musculoskeletal complications", which included physical activities - planned to be performed under the supervision of a physiotherapist - in people with obesity and in people with degenerative diseases of the knee and hip joints. However, the justification of the negative opinion indicated that the project contains many shortcomings and is formulated quite generally. This results in the inability to make a reliable as- 
sessment of its functioning and the assessment of effects (Opinion of the AOTMiT No. 08/2010).

Another reason for issuing negative opinions about PPZ projects in the area of therapeutic rehabilitation was the selection - by the local government unit - of an intervention with no proven effectiveness in clinical trials. This concerned $4 \mathrm{PPZ}$ projects, including one voivodeship project developed by the Opolskie Voivodeship - titled "Pulmonary rehabilitation for children under 18 in the favourable climate of the Jarnołtówek area". In justifying the negative opinion of this project, it was pointed out that many of the rehabilitation methods proposed have not been confirmed by research. This applies in particular to such methods as esthetotherapy, silvotherapy, folk therapy, singing therapy or speleotherapy. It was emphasized that even if some studies confirm the beneficial effect of staying in the microclimate of salt chambers (e.g., the sanitarium located in the Wieliczka Salt Mine created by M. Sulimowski), it does not necessarily follow that an equally beneficial microclimate exists in the gold, iron or copper mine drifts in Zlaté Hory (Czech Republic), where the children from the Jarnołtówek area were to travel three times during their stay (Opinion of the AOTMiT No. 238/2014).

The gmina PPZ projects assessed negatively due to the unproven effectiveness of the intervention also included the following projects:

- 'Treatment of obesity in health resorts', developed by the City of Kraków, whose main goal was to develop and implement a model for the treatment of obesity in groups at the highest risk of developing type 2 diabetes, hypertension and atherosclerosis (Opinion of the AOTMiT No. 51/2012, presented in more detail above).

- 'Prevention and rehabilitation of spine diseases in people of all ages', developed by the City of Kraków, under which an intervention was planned involving rehabilitation using the method and 'prophilactor' of Evminov (Opinion of the AOTMiT No. 223/2016).

- 'Halotherapy - pro-health prevention through inhalation in a salt cave for children and adolescents from the gmina of Polkowice, aged between 3 and 16', where the AOTMiT indicated lack of scientific evidence serving to assess halotherapy and data confirming the multidirectional mechanism of action of a dry sodium chloride aerosol and the suitableness of its use in the treatment and prevention of the diseases indicated (Opinion of the AOTMiT No. 213/2012).

The remaining 4 negative opinions of the AOTMiT were justified either by the wrong choice of the target group that was to be covered by the benefits (narrowing the treatment to a specific age group without justifying the decision) or the intervention was planned to include a small group of people and assumed that the benefits would be partially covered by the program participants, or the intervention was narrowed to a small number of treatments, which might limit the possibility of achieving positive effects of the planned rehabilitation.

\section{Discussion and conclusions}

While taking the decision to implement health policy programs, units of local government relatively often choose those that concern the rehabilitation of children and/or adults - in comparison with other areas of prevention or treatment. After preventive vaccination, this is the second most frequent area of health policy programs chosen by local governments. The most common goal of the proposed programs in this field is to improve the availability of therapeutic rehabilitation services and reduce the waiting time for benefits that are included in the list of guaranteed services and financed by public funds, mainly by the NFZ.

Health policy programs aimed at the implementation of therapeutic rehabilitation services in the local community do not always meet with the AOTMiT's approval. As indicated earlier, nearly every fourth such project is evaluated negatively. Although the quality of the PPZ projects the local governments submit for review to the AOTMiT is getting better, some projects are still poorly designed; some of the submitted projects do not contain key elements that are required by the AOTMiT. Formal errors and insufficient arguments are the most common reasons for issuing a negative opinion. Other reasons indicated by the Agency are an incorrectly planned target population or lack of scientific evidence confirming the effectiveness of the intervention or lack of clinical recommendations justifying its implementation in a given population.

The analysis of the reasons for issuing negative opinions on PPZs aimed at therapeutic rehabilitation shows unequivocally that by improving the quality (completeness and consistency) of the submitted projects, the vast majority of negative opinions could be avoided.

The latest legislative changes concerning the PPZ projects include the simplification of the process of issuing opinions and facilitating project preparation for local governments. As previously indicated, the AOTMiT has recently published a new PPZ model, which is available on its website, and is clearer and simpler. This should lead to a reduction in the percentage of negatively evaluated PPZ projects, including PPZs aimed at rehabilitation. This is crucial in the context of the new law regarding the principles of issuing opinions on and implementing PPZ projects, pursuant to which the implementation of the health policy program whose project was not submitted for opinion to the AOTMiT - despite the existence of such an obligation - and whose draft was negatively evaluated by the AOTMiT, in fact constitutes a breach of the public finance discipline.

Only by choosing interventions of proven results and cost-effectiveness is it possible to rationally spend funds available within the healthcare system, thus obtaining the greatest possible health effects. Financial shortages and the resulting inability to finance all desirable goods (including even effective therapies) require that decisions be made in all areas of human activity [14]. In the era of rising health care costs, the search for effective solutions and gaining economic benefits is the goal of all health 
systems, regardless of their organizational forms. Just as rationally functioning government units want to make the best choices having limited resources at their disposal, so do the decision-makers face choices restricted by the availability of resources [15]. The need to obtain a positive opinion of the AOTMiT on the planned PPZ projects is an expression of the progressing tendency towards rational public funds spending, which means having the certainty that selected interventions will bring health benefits to the local community. The new regulations may also motivate local governments to improve the quality of submitted projects, including projects aimed at interventions in the field of therapeutic rehabilitation, as nowadays negative opinions are most often given to projects that are incomplete, inconsistent or insufficiently justified by the needs of the local community.

While understanding and accepting the rationalization of activities - also in the field of therapeutic rehabilitation - we cannot overlook the difficulties in acquiring the scientific basis and practical evidence in the areas whose effects are not quickly obtained, require continuity and comprehensive activities. Therefore, along with the application of evaluations of rehabilitation programs by relevant agencies, it is necessary to develop methods that allow obtaining a health effect assessment in the long term and its multi-factorial impact. In addition to the strictly medical effect, it is necessary to take into account the effects associated with functional fitness and quality of life.

\section{Notes}

${ }^{1}$ The tasks of local government units at each level - that of the gmina, powiat and voivodeship - include those within health protection (in accordance with Article 7 paragraph 1 item 5 of the Act of 8 March 1990 on local government [gmina] - Journal of Laws 1990, No. 16 item 95, as amended; Article 4 paragraph 1 item 2 of the Act of June 5, 1998 on powiats - Journal of Laws 1998 No. 91, item 578, as amended; and Art. 14 item 1 point 2 of the Act of June 5, 1998 on voivodeships - Journal of Laws 1998 No. 91, item 576, as amended, respectively). The tasks of the local authorities in this area are specified in Art. 7-9 of the Act of 27 August 2004 on publicly-funded health care services (Journal of Laws 2004 No. 210 item 2135, as amended).

${ }^{2}$ Or minister (mainly the Minister of Health; only one PPZ was developed by a different sector - the Minister of Defence).

\section{References}

1. Czechowski K., Wilmowska-Pietruszyńska A., O potrzebie rehabilitacji kompleksowej, "Niepełnosprawność - zagadnienia, problemy, rozwiązania" 2016, 2 (19): 35-52.
2. Kawwa J, Wilmowska-Pietruszyńska A., Znaczenie rehabilitacji w zapobieganiu niepełnosprawności, "Niepełnosprawność - Zagadnienia, Problemy, Rozwiązania" 2016; 2 (19): 75-89.

3. Najwyższa Izba Kontroli (NIK), Dostępność i finansowanie rehabilitacji leczniczej. KZD-4101-04/2013. Nr ewid. 37/2014/P/13/131/KZD, Warszawa 2014.

4. Golinowska S., Sowa A., Wilmowska-Pietruszyńska A., Funkcjonowanie orzecznictwa lekarskiego oraz działalność lekarzy orzeczników w systemie zabezpieczenia społecznego i wspierania zatrudnienia, "Polityka Społeczna" 2012; 2: 26-32.

5. Ustawa $z$ dnia 27 sierpnia 2004 r. o świadczeniach opieki zdrowotnej finansowanych ze środków publicznych (Dz. U. $2004 \mathrm{Nr} 210$ poz. 2135 z późn. zm.).

6. Agencja Oceny Technologii Medycznych i Taryfikacji (AOTMiT), Praktyczne wskazówki dotyczace planowania, wdrażania oraz realizacji programów polityki zdrowotnej, wersja 1.1; http://www.aotm.gov.pl/www/wp-content/uploads/2016/08/Instrukcja_PPZ.pdf (accessed: 06.10.2017).

7. Agencja Oceny Technologii Medycznych i Taryfikacji (AOTMiT), Struktura PPZ; http://www.aotm.gov.pl/www/ wp-content/uploads/2016/08/Zal_4_16-02-12_struktura_programu_polityki_zdrowotnej.pdf (accessed: 06.10.2017).

8. Najwyższa Izba Kontroli (NIK), Realizacja programów polityki zdrowotnej przez jednostki samorzadu terytorialnego. KZD.430.001.2016. Nr ewid. 10/2016/P/15/063/KZD, Warszawa 2016.

9. Ustawa z dnia 17 grudnia 2004 r. o odpowiedzialności za naruszenie dyscypliny finansów publicznych (Dz. U. z 2017 r. poz. 1311 z późn. zm.).

10. Ustawa z dnia 29 września 2017 r. o zmianie ustawy o świadczeniach opieki zdrowotnej finansowanych ze środków publicznych oraz niektórych innych ustaw (Dz. U. z 2017 r. poz. 2110).

11. Agencja Oceny Technologii Medycznych i Taryfikacji (AOTMiT), Wzór programu polityki zdrowotnej; http://www.aotm. gov.pl/www/wp-content/uploads/25.07.17_nowy_wzor_PPZ. pdf (accessed: 24.10.2017).

12. Agencja Oceny Technologii Medycznych i Taryfikacji (AOTMiT), Opinie o projektach $P P Z$ realizowanych przez $J S T$; http://bipold.aotm.gov.pl/index.php/opinie-o-projektach-programow-zdrowotnych-realizowanych-przez-jst (accessed: 06.10.2017).

13. Christakis N.A., Fowler J.H., The spread of obesity in a large social network over 32 years, "N. Engl. J. Med.” 2007; 357: 370-379.

14. Drummond M.F., O’Brien B., Stoddart G.L., Torrance G.W., Metody badań ekonomicznych programów ochrony zdrowia, Via Medica, Gdańsk 2003.

15. Folland S., Goodman A.C., Stano M., Ekonomia zdrowia i opieki zdrowotnej, Wolters Kluwer Polska, Kraków 2013.

Przygotowanie do wydania elektronicznego publikacji-zadanie finansowane w ramach umowy Nr 780/P-DUN/2017 ze środków Ministra Nauki i Szkolnictwa Wyższego przeznaczonych na działalność upowszechniająca naukę. 